\title{
TANGGUNG GUGAT PEMEGANG HAK CIPTA TERHADAP PERBUATAN MELAWAN HUKUM PELANGGARAN HAK CIPTA
}

\section{Eko Rial Nugroho, Wahyu Priyanka NP}

Universitas Islam Indonesia

Contact: 094100405@uii.ac.id; wahyupriyanka@gmail.com

Diterima: 8 juli 2019

Direvisi: 8 Juli 2019

Disetujui: 5 Agustus 2019

Hak Cipta: (C)2019

Halaman: 23-37

\begin{abstract}
PT. ISM and FIFA have made and signed License Agreement in May $5^{\text {th }}, 2011$. The License Agreement related to delegation of certain rights of broadcasting which related on XX edition from football tournaments and other FIFA events. Based on this exclusivity, there are no other parties (Include but not limited to the broadcaster), who have right to (but not limited to) do socialization, marketing, and supervision of permission to use the 2014 Brazil World Cup broadcast commercially in commercial places. However, a party namely PT. SSM alleged to do act against the right to broadcast or airing or hold a Nonton Bareng event of 2014 Brazil World Cup commercially without having permission from PT. ISM. As a result of broadcasting the 2014 Brazil World Cup by PT. SSM, PT. ISM felt material and immaterial losses. The purpose of this study is to figure out whether Copyright infringement can be categorized as an unlawful act and to know how the legal protection for the Copyright license holder of unlawful act in the form of Copyright infringement.This Study is a normative legal study with qualitative analysis. This study concluded that PT. SSM has committed an unlawful act in the form of a Copyright infringement and the legal protection has given to copyrights license holder by taking legal action in the form of a lawsuit to the Commercial Court and requesting for compensation of unlawful act committed by PT. SSM
\end{abstract}

Keyword: Unlawful act, Copyrights, License, Legal protection 


\section{PENDAHULUAN}

Hukum Hak Kekayaan Intelektual adalah instrumen hukum yang digunakan untuk memproteksi kreasi-kreasi intelektual manusia yang telah diwujudkan secara nyata (bukan hanya ide atau gagasan)

(Riswandi, 2008).

Perlindungan hukum Hak Kekayaan Intelektual (selanjutnya disebut HKI) ialah hal (perbuatan) memperlindungi dan memproteksi kreasi-kreasi intelektual manusia yang telah diwujudkan secara nyata (bukan hanya ide atau gagasan) melalui instrumen hukum atau aturan di bidang HKI.

Hak Cipta sebagai bagian dari aturan dibidang HKI, merupakan hak ekslusif bagi pencipta untuk mengumumkan atau memperbanyak ciptaannya, yang timbul secara otomatis setelah suatu ciptaan dilahirkan tanpa mengurangi pembatasan menurut peraturan perundang-undangan yang berlaku berdasarkan prinsip deklaratif setelah suatu ciptaan diwujudkan dalam bentuk nyata tanpa mengurangi pembatasan sesuai dengan ketentuan peraturan perundang-undangan (Saidin, 2006).

Hak Cipta memiliki kedudukan tersendiri disamping HKI lain yang tergabung dalam hak kekayaan industri, atau dapat juga dikatakan bahwa Hak Cipta adalah hak immaterial, yaitu hak yang tidak dapat dilihat dan diraba tetapi dapat dimiliki. (Saidin, 1995).

Hak Cipta ini suatu hak yang harus lindungi karena apabila tidak dilindungi akan merugikan orang yang telah berinspirasi, berimajinasi dan berpikir untuk menciptakan sesuatu. "Pengorbanan" membuat dan menjadikan karya yang dihasilkan memiliki "nilai". Apabila ditambah dengan manfaat ekonomi yang dapat dinikmati, nilai ekonomi yang melekat menumbuhkan konsep property terhadap karya intelektual. Bagi dunia usaha, karya intelektual dikatakan sebagai aset perusahaan (Nainggolan, 2011).

Perlindungan hak cipta tidak diberikan kepada ide atau gagasan karena karya cipta harus memiliki bentuk yang khas, bersifat pribadi dan menunjukkan keaslian sebagai ciptaan yang lahir berdasarkan kemampuan, kreatifitas, atau keahlian sehingga ciptaan itu dapat dilihat, dibaca atau didengar. Alasan mendasar perlindungan terhadap Hak Kekayaan Intelektual (HKI) adalah untuk mengakui pemberian hak terhadap HKI yang berasal dari kemampuan intelektual seseorang sebagai perwujudan refleksi kepribadiannya atau perwujudan kualitas rasa, karsa, dan daya nalarnya. Semakin banyak dan berkualitas HKI yang dihasilkan seorang pendesain akan memberi nilai tambah terhadap martabat dan keuntungan ekonomi bagi dirinya (Damian, 2004).

Subjek hak cipta, bisa manusia dan badan hukum. Inilah yang oleh UUHC dinamakan dengan pencipta. Pencipta adalah seseorang atau beberapa orang yang secara sendiri-sendiri atau bersama-sama menghasilkan suatu ciptaan yang bersifat khas dan pribadi. Pencipta dapat juga diartikan sebagai seseorang atau beberapa orang yang secara sendiri-sendiri atau bersama-sama yang atas inspirasinya lahir suatu ciptaan berdasarkan kemampuan pikiran, imajinasi, kecekatan, keterampilan atau keahlian yang dituangkan dalam bentuk yang khas dan bersifat pribadi (Janed \& Nasution, 2013).

Ada 2 (dua) jenis pencipta atau subjek hukum yang bisa diberikan perlindungan hak cipta, perorangan dan badan hukum 
yaitu (Hidayah, 2007). Pencipta hak cipta otomatis menjadi pemegang hak cipta tidak harus penciptanya, tetapi bisa pihak lain yang menerima hak tersebut dari pencipta atau pihak lain yang menerima lebih lanjut hak tersebut dari pencipta atau pemegang hak cipta yang bersangkutan (Usman, 2003). Pemegang hak cipta adalah pencipta sebagai pemilik hak cipta atau orang lain yang menerima lebih lanjut hak dari orang tersebut di atas.

Secara garis besar Hak Cipta merupakan hak eksklusif yang terdiri dari hak moral (Hak untuk mendapatkan manfaat ekonomi atas ciptaan serta produk terkait dan hak ekonomi) Hak Cipta memberikan perlindungan hukum terhadap suatu karya cipta baik secara moral maupun secara ekonomi. Hak ekonomi dari hak cipta dapat beralih atau dialihkan kepada orang lain oleh pencipta, sedangkan hak moral tidak demikian, hak moral ini tetap mengikuti dan melekat pada diri pencipta, walaupun hak ekonomi hak cipta tersebut dapat beralih atau dialihkan kepada orang lain. Dengan demikian, yang dapat beralih atau dialihkan hanyalah hak ekonomi saja dari hak cipta, sementara hak moralnya tidak dapat dipisahkan dari diri penciptanya (Usman, 2003).

Perseroan Terbatas (PT), menurut Undangundang Nomor 40 Tahun 2007 tentang Perseroan Terbatas selanjutnya disebut UUPT Pasal 1 angka 1 adalah badan hukum yang merupakan persekutuan modal, didirikan berdasarkan perjanjian, melakukan kegiatan usaha dengan modal dasar yang seluruhnya terbagi dalam saham dan memenuhi persyaratan yang ditetapkan dalam undang-undang ini serta peraturan pelaksanaannya. Perseroan Terbatas sebagai badan hukum, memiliki status, kedudukan dan kewenangan yang dapat dipersamakan dengan manusia.
PT sebagai subjek hukum yang lahir dari undang-undang dan dikategorikan sebagai badan hukum. Perseroan Terbatas sebagai subyek hukum dapat melakukan hubungan hukum melalui orang-orang yang menjadi pengurus badan hukum tersebut, dan perbuatan para pengurus tersebut bukan untuk dirinya sendiri, tetapi untuk dan atas nama serta tanggung jawab badan hukum ( Khairandy, 2009; Ridho, 1986).

Badan hukum merupakan subjek hukum, maka badan hukum ini dapat melakukan kegiatan bisnis atas nama dirinya sendiri seperti manusia. Untuk itu agar badan hukum itu dapat bertindak seperti halnya "orang alamiah", diperlukan organ sebagai alat bagi badan hukum itu untuk menjalin hubungan hukum dengan pihak ketiga (Khairandy \& Malik, 2007).

PT sebagai subjek hukum dapat sebagai subjek hukum pemegang atas suatu HKI. PT secara hukum diakui dan dilindungi sebagai subjek hukum yang dapat dibebankan sebagai pemegang Hak Cipta.

\section{PT. INTER SPROT MARKETING} (selanjutnya disebut PT. ISM) suatu badan hukum yang didirikan berdasarkan Akta Pendirian Perseroan Terbatas dengan Nomor Akta 02 tertanggal 5 Oktober 2010, yang dibuat dihadapan Notaris Zacharias Omawele, SH, Notaris di Jakarta. PT. ISM telah mendapatkan pengesahan sebagai badan hukum Perseroan Terbatas sesuai dengan Keputusan Menteri Hukum dan Hak Asasi Manusia Republik Indonesia Nomor AHU-09377.AH.01.01 Tahun 2011. PT. ISM juga telah melakukan perubahan berdasarkan Akta Pernyataan Keputusan Rapat Umum Pemegang Saham Luar Biasa (RUPS) PT. INTER SPROT MARKETING Nomor 05 tertanggal 5 Mei 2014, dibuat dihadapan Notaris Irma Bonita, SH, Notaris di Jakarta, dan perubahan tersebut telah dicatatkan dalam perubahan data 
Perseroan PT. INTER SPROT MARKETING di Kementrian Hukum dan Hak Asasi Manusia Republik Indonesia Nomor AHU.08835.40.22.2014 tertanggal 19 Mei 2014.

PT. ISM menjalankan kegiatan usahanya yang bergerak dibidang kegiatan-kegiatan olahraga, baik di dalam negeri maupun di luar negeri sejak tahun 2010 hingga saat ini. Salah satu kegiatan keolahragaan yang berskala internasional adalah FIFA WORLD CUP Brazil 2014 (selanjutnya disebut Piala Dunia Brazil 2014). PT. ISM sebagai penerima lisensi dari FEDERATION INTERNATIONAL DE FOOTBALL ASSOCIATION (selanjutnya disebut FIFA) yang merupakan induk organisasi sepakbola internasional berkedudukan di Zurich, Swiss, guna menanyangkan siaran Piala Dunia Brazil 2014 ke seluruh wilayah Indonesia.

PT. ISM dan FIFA telah membuat dan menandatangani license Agreement tanggal 5 Mei 2011. Pihak PT. ISM selaku "Master Right Holder" atas Media Rights of 2014 FIFA WORLD CUP BRAZIL di seluruh wilayah Indonesia. Perjanjian lisensi tersebut berkaitan dengan pelimpahan dari hak-hak media tertentu yang ditimbulkan dalam kaitan dengan edisi XX dari turnamen sepakbola dan even-even FIFA lainnya (Putusan Nomor : 01/PDT.SUSHKI/2015/PN.NIAGA.Smg).

PT. ISM selaku penerima lisensi beritikad baik menjalankan kewajiban hukum dengan mencatatkan perjanjian lisensi tersebut di Direktorat Jenderal Hak Kekayaan Intelektual, Direktorat Hak Cipta Kementrian Hukum dan Hak Asasi Manusia Republik Indonesia, berdasakan Pasal 47 Undang-Undang Nomor 19 Tahun 2002 Tentang Hak Cipta (selanjutnya disebut UUHC). PT. ISM melalui Kuasa Hukumnya mengajukan permohonan Pencatatan
Perjanjian Lisensi tanggal 23 Mei 2014, dan diterima dan dicatatkan tanggal 23 Mei 2014.

PT. ISM telah memberikan sub lisensi hak media guna penanyangan Siaran Piala Dunia Brazil 2014 di wilayah Republik Indonesia kepada TV ONE dan ANTV secara eksklusif untuk menyiarkan acara/program Piala Dunia Brazil 2014 dengan sistem free to air broadcaster, dan kepada K-VISION dan VIVA+ secara eksklusif untuk menyiarkan/program Piala Dunia Brazil 2014 dengan sistem Pay TV Broadcaster serta untuk internet mobile rights kepada Domikado.

PT. ISM juga telah menunjuk PT. NONBAR atas hak-hak ekshibisi Publik dan hak-hak areal komersial atau kepentingan komersial secara eksklusif di wilayah Indonesia sebagai koordinator tunggal untuk aktifitas nonton bareng berdasarkan Surat Penunjukkan PT. ISM kepada PT. NONBAR No. 008/ISM/Srt.P/2013 tanggal 12 November 2013 dan Pembaharuan Surat Penunjukkan Nomor 010/ISM/Srt.P/V/2014 tanggal 10 Mei 2014. Berdasarkan eksklusifitas ini, tidak ada pihak lain (termasuk tetapi tidak terbatas pada para broadcaster), yang berhak untuk (namun tidak pada terbatas pada) melakukan sosialisasi, pemasaran dan pengawasan ijin penggunaan siaran Piala Dunia Brazil 2014 secara komersial di tempat-tempat komersial (hotel, mall, gedung pertemuan, restoran, café, lounge dan tempat-tempat berkumpulnya masyarakat lainnya) yang oleh penyelenggaraannya dikomersialkan atau pemilik tempat tersebut mendapatkan keuntungan secara komersial dengan adanya siaran Piala Dunia Brazil 2014.

Namun, dari beberapa pihak yang mendapatkan hak guna mempromosikan siaran Piala Dunia Brazil 2014, ada salah 
satu pihak yaitu PT. SUN STAR MOTOR (selanjutnya disebut PT. SSM) yang diduga telah mempromosikan, mengumumkan, menginformasikan kepada umum bahwa di tempat PT. SSM menayangkan dan mengadakan kegiatan acara Nonton Bareng Piala Dunia Brazil 2014 tanggal 13 Juli 2014 secara komersil. PT. SSM mencantumkan gambar/bentuk merk produk kendaraan bermotor yaitu Mitsubishi Motor sebagai sponsor dalam kegiatan nonton bareng Piala Dunia Brazil 2014, meskipun Mitsubishi Motor tidak menjadi sponsor resmi even Piala Dunia Brazil 2014.

PT. SSM diduga melakukan perbuatan tanpa hak menyiarkan atau menanyangkan atau mengadakan kegiatan nonton bareng Piala Dunia Brazil 2014 secara komersiil dan tidak memiliki ijin lisensi dari PT. ISM atau PT. NONBAR yang telah ditunjuk PT. ISM. PT. SSM juga diduga tanpa hak telah menyandingkan logo Merk dan dua produk kendaraan pabrikan Mitsubishi disamping logo Piala Dunia Brazil 2014.

Pihak PT. NONBAR telah memberikan somasi kepada pihak PT. SSM sebanyak dua kali, somasi pertama, Nomor 311/SKBL-WP/IX/2014 tertanggal 1 September 2014 dan somasi kedua, Nomor 323/SKBL-WP/IX/2014 tertanggal 13 September 2014.

Pihak PT. SSM menanggapi somasi PT. NOBAR dengan menulis permohonan maaf melalui media cetak Jawa Post, hari Selasa, 7 Oktober 2014 di dalam halaman 7, kolom PENGUMUMAN dengan judul "PERMOHONAN MAAF" yang isi kutipan sebagai berikut "Berkenaan dengan pengadaan nonton bareng final Piala Dunia Brazil 2014 tanggal 13 Juli 2014 di selasela acara buka puasa bersama dan sahur bersama di kantor kami di Jalan MT. Haryono 1012 Semarang, yang dilakukan tanpa ijin PT. NONBAR cq. PT ISM selaku pemegang lisensi dari FIFA, bersama ini kami, PT. SSM Cabang Semarang, menyampaikan permintaan maaf kepada PT. NONBAR cq. PT ISM, dikarenakan semata-mata sebab ketidaktahuan dan ketidaksengajaan pihak kami, dan bersedia untuk membayar ijin penyelenggaraan sesuai ketentuan yang ada tertanda BM. PT. SSM.

Namun, setelah adanya permintaan maaf di media cetak, pihak PT. SSM belum menindaklanjuti lagi untuk menyelesaikan masalah dengan PT. NONBAR dan PT. ISM. Akibat perbuatan penanyangan siaran Piala Dunia Brazil 2014 oleh pihak PT. SSM tersebut pihak PT. NONBAR dan PT. ISM merasa dirugikan baik materiil dan immaterial.

\section{METODOLOGI PENELITIAN}

Penelitian ini merupakan penelitian hukum normatif, yaitu penelitian yang dilakukan dengan mendasarkan pada data kepustakaan sebagai data utamanya yang merupakan data sekunder dan berupa bahan-bahan hukum. Bahan hukum yang digunakan antara lain Undang-Undang Nomor 28 Tahun 2014 juncto UndangUndang Nomor 19 Tahun 2002 Tentang Hak Cipta, Peraturan Pemerintah Nomor 36 Tahun 2018 Tentang Pencatatan Perjanjian Lisensi Kekayaan Intelektual, Putusan Nomor 01/PDT. SUSHKI/2015/PN. NIAGA.Smg, Putusan Nomor 517 K/Pdt.Sus-HKI/2015. Bahan-bahan hukum yang telah dikelompokkan dan diklasifikasikan, selanjutnya dianalisis dengan menggunakan analisis kualitatif. Dengan analisis kualitatif tersebut, langkah-langkah yang ditempuh didasarkan logika yuridis, sehingga permasalahannya dapat dijelaskan dalam penelitian ini. 


\section{HASIL DAN PEMBAHASAN}

\section{Perbuatan Melawan Hukum Berupa Pelanggaran Hak Cipta}

PT. ISM adalah selaku penerima lisensi dari FIFA atas Siaran Piala Dunia Brazil 2014. PT. ISM selaku penerima lisensi merupakan Master Rights Holder di seluruh wilayah Republik Indonesia, dan telah diberikan hak media berupa hak ekshibisi publik (hak-hak areal komersial) Hak ekshibisi publik (hak-hak areal komersial) adalah semua hak untuk: Pertama, menstrasmisikan dengan bantuan sesuatu media apapun sesuatu material audio saja, visual diam atau bergerak saja, material audiovisual, data dan/atau material teks atau bertalian dengan kompetisi atau suatu upacara atau event FIFA lainnya untuk ekshibisi kepada dan ditonton atau didengar oleh pemirsa yang berlokasi entah dimana dalam bioskop, bar, restoran, stadion, kantor, lokasi konstruksi, oil rig, kendaraan di atas air, bus, kereta api, bangunan angkatan bersenjata, bangunan pendidikan, rumah sakit dan suatu tempat lainnya selain dari sebuah hunian pribadi; Kedua, mengorganisasikan dan mempertontonkan sesuatu event berkaitan dengan hal itu di mana para hadirin dapat menonton dan/atau mendengar kepada transmisi tersebut (entah ya atau tidak suatu tontonan seperti itu terbuka bagi masyarakat luas atau sebaliknya); dan ketiga, mengeksploitasi sesuatu dan semua peluang komersial (termasuk misalnya pungutan masuk ke sponsor siaran dan peluang pemasok) yang ditimbulkan dari dan/atau ekshibisi, hak-hak ekshibisi public mengecualikan hak dalam pemotongan (in flight right). PT. ISM sebagai pemegang lisensi hak media dalam konten Hak Cipta, berhak memberi ijin atau melarang siapapun untuk mengambil keuntungan secara komersial atas siaran Piala Dunia Brazil 2014.
PT. ISM telah memberikan sub lisensi hak media guna penanyangan Siaran Piala Dunia Brazil 2014 di wilayah Republik Indonesia kepada TV ONE dan ANTV secara eksklusif untuk menyiarkan acara/program Piala Dunia Brazil 2014 dengan sistem free to air broadcaster, dan kepada K-VISION dan VIVA+ secara eksklusif untuk menyiarkan/program Piala Dunia Brazil 2014 dengan sistem Pay TV Broadcaster serta untuk internet mobile rights kepada Domikado.

PT. ISM juga telah menunjuk PT. NONBAR atas hak-hak ekshibisi Publik dan hak-hak areal komersial atau kepentingan komersial secara eksklusif di wilayah Indonesia sebagai koordinator tunggal untuk aktifitas nonton bareng berdasarkan Surat Penunjukkan PT. ISM kepada PT. NONBAR No. 008/ISM/Srt.P/2013 tanggal 12 November 2013 dan Pembaharuan Surat Penunjukkan Nomor 010/ISM/Srt.P/V/2014 tanggal 10 Mei 2014. Berdasarkan eksklusifitas ini, tidak ada pihak lain (termasuk tetapi tidak terbatas pada para broadcaster), yang berhak untuk (namun tidak pada terbatas pada) melakukan sosialisasi, pemasaran dan pengawasan ijin penggunaan siaran Piala Dunia Brazil 2014 secara komersial di tempat-tempat komersial (hotel, mall, gedung pertemuan, restoran, café, lounge dan tempat-tempat berkumpulnya masyarakat lainnya) yang oleh penyelenggaraannya dikomersialkan atau pemilik tempat tersebut mendapatkan keuntungan secara komersial dengan adanya siaran Piala Dunia Brazil 2014.

Berdasarkan fakta-fakta yang terungkap di persidangan diantaranya adanya bukti pemasangan spanduk pemberitahuan acara nonton bareng Final Piala Dunia Brazil 2014 di Sun Star Motor di Jalan MT. Haryono Semarang. Spanduk tersebut 
terdapat gambar logo Piala Dunia Brazil 2014 yang disandingkan dengan gambar produk kendaraan Mitsubishi Outlander Sport warna putih dan Pajero Sport warna hitam berikut tulisan voucher belanja 3 (tiga) juta rupiah. Bukti lainnya, adanya foto pemasangan big screen yang digunakan PT. SSM untuk event nonton bareng penanyangan Piala Dunia Brazil 2014 di halaman show room/dealer PT. SSM. Adanya beberapa saksi dari pihak PT. ISM yang melihat penanyangan nonton bareng Final Piala Dunia Brazil 2014 bersama pengunjung lainnnya, dan melaporkan kepada PT. ISM. PT. ISM menindaklanjuti dengan melakukan teguran/somasi kepada pihak PT. SSM sebanyak 2 (dua) kali, 1 September 2014 dan 13 Septmber 2014( Vide Putusan Nomor 01/PDT. SUS-HKI/2015/PN. NIAGA. Smg).

Berdasarkan fakta-fakta di persidangan tersebut, pihak PT. SSM telah mempertunjukkan sebuah konten yang dilakukan di area komersial karena tujuannya mengambil keuntungan ekonomi, dan merupakan pelanggaran Hak Cipta dengan menggunakan hak eksklusif tanpa ijin. Hal ini membuktikan bahwa pihak PT. SSM telah terbukti melakukan perbuatan melawan hukum berupa pelanggaran hak cipta, yaitu tanpa ijin melakukan hak siar (hak-hak areal komersial) dan menimbulkan kerugian dari pemegang lisensi yaitu PT. ISM.

PT. SSM telah terbukti melakukan perbuatan melawan hukum berupa pelanggaran hak cipta dan diharuskan membayar biaya lisensi nonton bareng atau penanyangan siaran Piala Dunia Brazil 2104 sebagai sponsor ship, mengingat pihak PT. SSM telah jujur dan mempunyai itikad baik meminta maaf atas kesalahannya melalui media massa, dan penyelenggaraan nonton bareng tersebut dapat dikategorikan sebagai kegiatan sosial (menunggu saat sahur untuk puasa) tanpa dipungut biaya, serta bentuk media yang digunakan sebatas spanduk yang beisi pengumuman dengan menyandingkan mobil produk Mitsubishi, harus dimaknai tidak sepenuhnya menjadikan PT. SSM sebagai sponsorship yang menimbulkan adanya lonjakan pembelian yang signifikan.

\section{Perlindungan hukum pemegang lisensi atas perbuatan yang dilakukan PT. SSM} Perlindungan hukum atas Hak Cipta sebagai upaya mewujudkan iklim yang baik bagi berkembangnya penciptaan dibidang ilmu pengetahuan, seni dan sastra (Firmansyah, 2011). Indonesia telah ikut menandatangani Perjanjian Wold Trade International termasuk perjanjian tentang Trade Related Aspect of Intelectual Property Rights, maka UUHC perlu menyesuaikan guna memenuhi kewajiban internasional , termasuk ketentuan yang berkaitan dengan perlindungan Hak Milik Intelektual (Gautama\& Winata, 1997).

Bidang kajian HKI mendapat cukup banyak perhatian baik dikalangan masyarakat dan pemerintah demi perlindungan hukum. Hal ini penting, mengingat perlindungan hukum ini untuk mendorong tumbuhnya kreatifitas masyarakat dengan berbagai karya cipta dan penemuan-penemuan (invention) yang berguna dalam pembangunan di Indonesia (Anjelfa, 2015: 320).

Perlindungan hukum terhadap Hak Cipta, selain untuk melindungi kepentingan lembaga, badan hukum dan individu, juga diperlukan bagi suatu negara guna mendapatkan kepercayaan dari dunia internasional dan menghindari sanksi internasional. Kepercayaan dunia internasional sangat dibutuhkan dengan harapan dapat meningkatkan 
pertumbuhan ekonomi dalam negeri.

Perlindungan hukum yang ada merupakan upaya yang diatur dalam UUHC guna mencegah ada dan terjadinya pelanggaran HKI yang dilakukan oleh orang-orang yang tidak berhak. Pelanggar yang telah melakukan pelanggaran HKI harus diproses hukum dan jika dalam persidangan terbukti adanya pelanggaran terhadap HKI, maka harus dijatuhi hukuman sesuai dengan ketentuan peraturan perundang-undangan yang berlaku. UUHC mengatur jenis-jenis perbuatan pelanggaran dan ancaman hukumannya, baik secara perdata maupun pidana. UUHC ini memuat sistem deklaratif (first to use system), yaitu perlindungan hukum hanya diberikan kepada pemegang/pemakai pertama atas Hak Cipta. Apabila ada pihak lain yang mengaku sebagai pihak yang berhak akan Hak Cipta, maka pemegang/pemakai pertama harus membuktikan bahwa dia sebagai pemegang/pemakai pertama yang berhak atas hasil ciptaan tersebut (Maarif, 2017).

Intelectual Property Rights atau HKI merupakan kekayaan intelektual yang mempunyai manfaat ekonomi yang terkandung di dalamnya nilai-nilai ekonomi. HKI memiliki ciri bernilai komersial dan merupakan hak pribadi yang dapat dilisensikan dan merupakan hak monopoli guna mencegah orang lain mengunakannya secara tanpa izin (Purwaningsih, 2005).

Pemanfaatan nilai ekonomi HKI pencipta tidak dapat melakukannya sendiri, dan berdasarkan undang-undang, HKI diperbolehkan untuk memberikan lisensi. Lisensi yang berasal dari bahasa latin "licentia" (Saleh, 1991).

Prinsipnya mekanisme lisensi adalah memberikan kebebasan atau izin kepada seseorang atau pihak lain untuk menggunakan sesuatu yang sebelumnya tidak boleh dipergunakannya (Hidayati, 2014).

Menurut Gunawan Widjaja (Widjaja 2001: 11) lisensi selalu dihubungkan dengan kewenangan dari privilege untuk melakukan sesuatu oleh seseorang atau pihak tertentu. Kewenangan yang ada di diri pencipta diserahkan kepada pihak lain melalui perjanjian lisensi. Semua pihak yang tidak memiliki lisensi dari si pencipta, maka pihak lain tersebut tidak berhak menggunakan Hak Cipta dalam bentuk apapun dengan tujuan komersial. Lisensi adalah izin yang diberikan oleh Pemegang Hak Cipta atau pemegang hak terkait kepada pihak lain untuk mengumumkan dan/atau memperbanyak ciptaannya atau produk hak terkaitnya dengan persyaratan tertentu (Pasal 1 angka 14 \& pasal 1 angka 20 UUHC).

Lisensi yang diwujudkan secara tertulis, berdasarkan peraturan perundangundangan di Indonesia harus dicatatkan di Dirjen HKI di Kementrian Hukum dan Hak Asasi Manusia Republik Indonesia. Apabila perjanjian lisensi tersebut tidak dicatatkan, maka perjanjian lisensi tersebut tidak mempunyai akibat hukum bagi pihak ketiga.

Prinsip lisensi, pertama, adanya izin yang diberikan pemegang hak; kedua,izin yang diberikan dalam bentuk perjanjian; ketiga, izin pemberian hak untuk manfaat ekonomi; keempat, izin yang diberikan untuk hak perlindungan; dan kelima, izin dikaitkan dengan waktu dan syarat tertentu (Widjaja, 2001).

Terkait dengan Undang-Undang Nomor 5 Tahun 1999 Tentang Larangan Praktik Monopoli dan Persaingan Usaha Tidak Sehat (UU Persaingan Usaha) menyatakan 
bahwa perjanjian-perjanjian yang berhubungan dengan HKI, misalnya lisensi paten, hak cipta, desain industri, rangkaian sirkuit terpadu, rahasia dagang dan perjanjian yang berhubungan dengan franchice dikecualikan dari ketentuan UU Persaingan Usaha ini (Purwaningsih, 2005).

Pemberian lisensi sebagai pemberian izin kepada penerima lisensi untuk memperbanyak dan menjual hasil karya cipta pemberi lisensi. Hasil jualan tersebut memberikan keuntungan kepada penerima lisensi yang tidak dinikmati seluruhnya, melainkan sebagian merupakan hak pemberi lisensi yang wajib diserahkan kepadanya. Sebagian keuntungan penerima lisensi yang diberikan kepada pemberi lisensi merupakan royalti. Royalti adalah imbalan atas pemanfaatan hak ekonomi suatu ciptaan atau produk hak terkait yang diterima oleh pencipta atau pemilik hak terkait (Pasal 1 angka 2, UUHC).

Hal inilah yang menjadi dasar dalam pemberian lisensi bahwa pemberian lisensi ini disertai dengan kewajiban pemberian royalti penerima lisensi kepada pemegang Hak Cipta. Jumlah royalti. yang wajib dibayarkan penerima lisensi kepada pemegang Hak Cipta berdasarkan kesepakatan kedua pihak dengan berpedoman kesepakatan organisasi profesi.

Proses perjanjian lisensi berawal dari kepemilikan hak eksklusif. Pemberian lisensi merupakan suatu hak khusus yang hanya dapat diberikan oleh pemberi lisensi atas kehendaknya sendiri, kepada satu atau lebih penerima lisensi yang menurut pertimbangan pemberi lisensi dapat menyelenggarakan, mengelola atau melaksanakan HKI yang dimiliki pemberi lisensi (Widjaja, 2001).
Hak Eksklusif ini terdiri 2 (dua) macam yakni, pertama, hak eksklusif atas ekspresi dari sebuah ide (hak cipta), dan kedua, hak eksklusif yang terkait dengan hak cipta (hak terkait). Kedua hak tersebut memungkinkan dimanfaatkan oleh pemegang hak eksklusif dan bisa juga dialihkan kepada pihak lain. Proses peralihan dengan 2 (dua) cara, pertama, pengalihan hak dengan cara assignment (pengalihan hak), misalnya jual beli, wasiat, hibah, dan kedua, melalui lisensi atau ijin.

Lisensi terdiri dari 2 (dua) jenis, lisensi eksklusif dan lisensi non eksklusif, serta di dalam Undang-Undang Hak Cipta yang baru ditambahkan lisensi wajib (Pasal 84 UUHC) yang itu dilaksanakan atas dasar melalui permohonan ke Direktorat Jenderal Hak Kekayaan Intelektual Kementrian Hukum dan Hak Asasi Manusia Republik Indonesia (selanjutnya disebut Dirjen HKI).

Lisensi eksklusif ini merupakan lisensi yang dibatasi penggunaannya hanya untuk wilayah tertentu. Karakteristik lisensi dalam kasus penyiaran Piala Dunia Brazil 2014 termasuk lisensi eksklusif karena penyiarannya hanya untuk wilayah Indonesia saja. Sehingga di luar Pihak PT. ISM tidak ada lagi pemegang lisensi lainnya. Apabila ada pihak lain (sub lisensi) lain selain pihak PT. ISM, harus mendapat persetujuan dari FIFA sebagai pemegang hak eksklusif (Pemegang Hak Cipta dapat mengumumkan dan mempunyai 2 esensi yaitu hak ekonomi dan hak moral. Hak ekonomis (economic rights). Hak ekonomis adalah hak yang dimiliki oleh seorang pencipta untuk mendapatkan keuntungan atas ciptaannya. Undang-undang Hak Cipta Indonesia memberi hak ekonomis kepada pencipta, antara lain; hak untuk memperbanyak, hak untuk adaptasi, hak 
untuk distribusi; Hak moral (moral rights). Hak moral adalah hak khusus serta kekal yang dimiliki si pencipta atas hasil ciptaannya, dan hak itu tidak dipisahkan dari penciptanya. Hak moral ini adalah hak pencipta atau ahli warisnya, untuk menuntut kepada Pemegang Hak Cipta supaya nama Pencipta tetap dicantumkan pada Ciptaannya; Memberi persetujuan dalam perubahan hak Ciptaannya; Memberi persetujuan terhadap perubahan atau nama samaran pencipta; Menuntut seseorang yang tanpa persetujuannya meniadakan nama Pencipta yang tercantum pada ciptaannya). Hak kepemilikan eksklusif FIFA dapat dikategorikan sebagai kategori hak cipta bukan hak terkait, karena mengingat FIFA bukan sebagai lembaga penyiara, bukan produsen rekaman, bukan sebagai pelaku, namun FIFA membuat sebuah rekaman dalam bentuk gambar bergerak yang dinamakan Karya Sinematografi (Karya sinematografi adalah ciptaan yang berupa gambar bergerak (moving images) antara lain film documenter, film iklan, reportase atau film cerita yang dibuat dengan scenario, dan film kartun. Karya sinematografi dapat dibuat dalam pita seluloid, pita video, piringan video, cakram optic dan/atau media lain yang memungkinkan untuk dipertunjukkan di bioskop, layar lebar, televise atau media lainnya. Sinematografi merupakan salah satu contoh bentuk audiovisual., lihat Pasal 40 huruf $m$, UUHC).

FIFA merancang dan menginisiasi event Piala Dunia Brazil 2014, dan mewujudkan dalam bentuk karya kreatif yang disebut karya ciptaan, serta ciptaan ini dapat disebut sebagai karya sinematografi gambar bergerak (moving image). FIFA menyusun event, kapan jadwal pertandingan seperti apa prosesnya dan kapan pertandingan itu dilaksanakan sebagai proses pengelolaan event, dengan skema proses penyisihan, semifinal dan final yang diekspresikan dalam bentuk gambar bergerak yang disebut sinematografi.

Dengan demikian Pihak FIFA melisensikan hak eksklusif atas karya sinematografi kepada Pihak PT. ISM. Atas dasar tersebut, maka substansi kasus a quo mengenai hak cipta, khususnya dalam hal penerima lisensi yang memanfaatkan dan menggunakan hak cipta yang dimiliki oleh FIFA (Vide Putusan Nomor 01/PDT. SUSHKI/2015/PN. NIAGA. Smg).

Terkait dengan perjanjian lisensi yang harus dicatatkan, sebagai amanat UUHC Pasal 83 ayat (1), memang belum ada peraturan pelaksanaanya (Permenrin No 36/2018). Namun belum adanya peraturan pelaksananya tersebut tidak menjadi kendala dalam pencatatan lisensi.

Berdasarkan pengalaman dan kebiasaan yang terjadi, pencatatan lisensi (mengingat belum adanya peraturan pelaksananya saati itu) didasarkan beberapa hal, diantaranya dilihat asas itikad baik para pihak yang membuat perjanjian lisensi. Para pihak sadar bahwa membuat perjanjian lisensi tidak sekedar ingin dilindungi dari para pihak-pihaknya, tetapi juga ingin dilindungi dari pihak ketiga. Pencatatan lisensi berdampak mengikatnya perjanjian lisensi terhadap pihak ketiga. Berdasarkan itikad baik ini, sudah seharusnya para pihak yang ingin mencatatkan perjanjian lisensi diterima negara, harus diberikan perlindungan hukum. Hal lainnya yang sudah menjadi "hukum kebiasaan" bahwa kebiasaan pencatatan perjanjian lisensi memang diterima oleh Direktorat Jenderal Hak Kekayaan Intelektual dan hal ini menjadi hukum yang mengikat juga meskipun belum ada hukum yang sifatnya tertulis. Adanya Peraturan Pemerintah Nomor 45 
Tahun 2014 Tentang Penerimaan Negara Bukan Pajak, secara umum disebutkan bahwa adanya biaya pencatatan lisensi, dan pencatatan ini sifatnya resmi dan masuk ke kas negara, sehingga negara wajib melindungi para pihak yang dengan itikad baik mencatatkan perjanjian lisensi kepada negara.

Adanya "kekosongan hukum" dalam hal peraturan pelaksananya belum ada, maka asas hukum digunakan sebagai "pemecah" kebuntuan hukum para pihak. Adanya asas itikad baik dan kebiasaan tersebut, sudah sepantasnya pihak yang mencatatkan perjanjian lisensi sebagai amanah peraturan perundang-undangan mendapatkan perlindungan hukum yang layak oleh negara.

Pencatatan bersifat administratif, sehingga berbeda dengan pendaftaran yang meminta hak hukum. UUHC menyatakan bahwa pencatatan hanya merupakan tindakan administratif bukan tindakan meminta hukum, dan yang terpenting dalam pencatatan adalah bukan sertifikatnya namun bukti pencatatan lisensi tersebut, biasanya dalam bentuk stempel. Praktik hukumnya pencatatan lisensi hanya sebatas diparaf, tanggal dan diberi stempel Dirjen HKI, dan jika permohonan ditolak, maka surat permohonan tidak diterima, dan Dirjen HKI mengeluarkan surat tentang tidak diterima permohonan tersebut. Akibat hukumnya, ciptaan tersebut tidak mencakup substansi, hanya terkait administrasi saja dan tidak mengikat pihak ketiga (Vide Putusan Nomor 01/PDT. SUSHKI/2015/PN. NIAGA. Smg).

PT. ISM telah memberikan sub lisensi hak media guna penanyangan Siaran Piala Dunia Brazil 2014 di wilayah Republik Indonesia kepada TV ONE dan ANTV secara eksklusif untuk menyiarkan acara/program Piala Dunia Brazil 2014 dengan sistem free to air broadcaster, dan kepada K-VISION dan VIVA+ secara eksklusif untuk menyiarkan/program Piala Dunia Brazil 2014 dengan sistem Pay TV Broadcaster serta untuk internet mobile rights kepada Domikado.

PT.ISM juga telah menunjuk PT. NONBAR atas hak-hak ekshibisi Publik dan hak-hak areal komersial atau kepentingan komersial secara eksklusif di wilayah Indonesia sebagai koordinator tunggal untuk aktifitas nonton bareng berdasarkan Surat Penunjukkan PT. ISM kepada PT. NONBAR No. 008/ISM/Srt.P/2013 tanggal 12 November 2013 dan Pembaharuan Surat Penunjukkan Nomor 010/ISM/Srt.P/V/2014 tanggal 10 Mei 2014. Berdasarkan eksklusifitas ini, tidak ada pihak lain (termasuk tetapi tidak terbatas pada para broadcaster), yang berhak untuk (namun tidak pada terbatas pada) melakukan sosialisasi, pemasaran dan pengawasan ijin penggunaan siaran Piala Dunia Brazil 2014 secara komersial di tempat-tempat komersial (hotel, mall, gedung pertemuan, restoran, café, lounge dan tempat-tempat berkumpulnya masyarakat lainnya) yang oleh penyelenggaraannya dikomersialkan atau pemilik tempat tersebut mendapatkan keuntungan secara komersial dengan adanya siaran Piala Dunia Brazil 2014.

Namun, ada salah satu pihak yaitu PT. SSM yang diduga telah mempromosikan, mengumumkan, menginformasikan kepada umum bahwa di tempat PT. SSM menayangkan dan mengadakan kegiatan acara Nonton Bareng Piala Dunia Brazil 2014 tanggal 13 Juli 2014 secara komersiil. PT. SSM mencantumkan gambar/bentuk merk produk kendaraan bermotor yaitu Mitsubishi Motor sebagai sponsor dalam kegiatan nonton bareng Piala Dunia Brazil 2014, meskipun Mitsubishi Motor tidak 
menjadi sponsor resmi event Piala Dunia Brazil 2014.

PT. SSM diduga melakukan perbuatan tanpa hak menyiarkan atau menanyangkan atau mengadakan kegiatan nonton bareng Piala Dunia Brazil 2014 secara komersiil dan tidak memiliki ijin lisensi dari PT. ISM atau PT. NONBAR yang telah ditunjuk PT. ISM. PT. SSM juga diduga tanpa hak telah menyandingkan logo Merk Mitsubishi dan dua produk kendaraan pabrikan Mitsubishi disamping logo Piala Dunia Brazil 2014.

Pihak PT. NONBAR telah memberikan somasi kepada pihak PT. SSM sebanyak dua kali, dan pihak PT. SSM menanggapi somasi PT. NOBAR dengan menulis permohonan maaf melalui media cetak Jawa Post. Namun, setelah adanya permintaan maaf di media cetak, pihak PT. SSM belum menindaklanjuti lagi untuk menyelesaikan masalah dengan PT. NONBAR dan PT. ISM. Akibat perbuatan penanyangan siaran Piala Dunia Brazil 2014 oleh pihak PT. SSM tersebut pihak PT. NONBAR dan PT. ISM merasa dirugikan baik materiil dan immaterial.

Terjadinya sengketa (As'Edi, 2012) mengenai Hak Cipta karena adanya pelanggaran yang dilakukan oleh pihakpihak tertentu tanpa hak melakukan perbuatan-perbuatan tertentu yang mengakibatkan pemegang Hak Cipta mengalami kerugian dengan tujuan untuk memperoleh keuntungan ekonomi dari berbagai sumber atau berbayar (Rumbekwan, 2016).

Bentuk sengketa dalam Hak Cipta, antara lain:

1. Sengketa berupa perbuatan melawan hukum;

2. Perjanjian lisensi; dan
3. Sengketa mengenai tarif dalam penarikan imbalan atau royalti ( Pasal 95 (1) UUHC).

Apabila terjadi pelanggaran hukum atas Hak Cipta, maka pencipta atau pemegang Hak Cipta atau hak terkait lainnya dapat mengajukan gugatan atas pelanggaran Hak Cipta di Pengadilan Niaga, sesuai dengan tata cara gugatan yang telah diatur UUHC (Ismail, 2018).

Perbuatan pelanggaran Hak Cipta merupakan perbuatan melawan hukum yang dapat mengakibatkan kerugian baik pencipta atau pemegang Hak Cipta, negara, masyarakat. Pemegang Hak Cipta dan turunannya berhak meminta kepada Pengadilan (Niaga) agar menghukum pelanggar Hak Cipta menyerahkan seluruh dan/atau sebagian penghasilan atau pendapatan yang diterima oleh pelanggar Hak Cipta sebagai hasil pelanggaran Hak Cipta atau dengan cara melanggar Hak Cipta.

Berdasarkan kasus a quo, PT. ISM berhak mengajukan tanggung gugat atas pelanggaran oleh pihak PT. SSM, dengan dasar perbuatan melawan hukum berupa pelanggaran hak cipta, karena telah mempertunjukkan sebuah konten yang dilakukan di area komersial karena tujuannya mengambil keuntungan ekonomi, dan merupakan pelanggaran Hak Cipta dengan menggunakan hak eksklusif tanpa ijin. Pemegang Hak Cipta mengalami kerugian terhadap perbuatan melawan hukum yang dilakukan PT. ISM. UUHC memberikan kebebasan kepada pemegang Hak Cipta untuk melakukan gugatan, apabila pemegang Hak Cipta merasa haknya dilanggar dan menimbulkan kerugian bagi pemegang Hak Cipta.

PT. ISM berhak mengajukan gugatan atas dasar perbuatan melawan hukum berupa 
pelanggaran Hak Cipta ke Pengadilan yang berwenang menangani penyelesaian sengketa Hak Cipta yaitu Pengadilan Niaga(Pasal 95 ayat (2), (3) UUHC) Pengadilan Niaga sebagai kewenangan absolut pengadilan terhadap sengketa Hak Kekayaan Intelektual, khususnya Pengadilan Niaga Semarang sebagai kompetensi relatif, mengingat pihak PT. SSM, selaku pihak Tergugat beralamat di Jalan MT. Haryono Nomor 1012 Semarang Jawa tengah, berdasarkan asas actor sequitur forum rei. Asas tersebut diatur dalam Pasal 118 ayat (1) Herzein Inlandsch Reglement (HIR) yang menentukan bahwa yang berwenang mengadili suatu perkara adalah pengadilan negeri tempat tinggal Tergugat.

Terkait dengan kerugian, UUHC yang baru (Undang-Undang Nomor 28 Tahun 2014) menggunakan frasa "ganti rugi" dengan definisi adalah pembayaran sejumlah uang yang dibebankan kepada pelaku pelanggaran hak ekonomi Pencipta, Pemegang Hak Cipta dan/atau pemilik Hak Terkait berdasarkan putusan pengadilan perkara perdata atau pidana yang berkekuatan hukum tetap atas kerugian yang diderita Pencipta, Pemegang Hak Cipta dan/atau pemilik Hak Terkait. Sedangkan dalam UUHC yang lama (Undang-Undang Nomor 19 Tahun 2002) tidak memberikan definisi terkait kerugian (ganti rugi).

Sehingga terkait dengan makna kerugian baik UUHC yang baru dan yang lama tidak ada ketentuan spesifik yang mengatur hal tersebut, dan dapat mengacu kepada prinsip umum hukum perdata bahwa kerugian dapat berupa kerugian materiil dan kerugian immaterial.

\section{KESIMPULAN}

1. PT. SSM telah terbukti melakukan perbuatan melawan hukum berupa pelanggaran Hak Cipta cipta, karena telah mempertunjukkan sebuah konten yang dilakukan di area komersial karena tujuannya mengambil keuntungan ekonomi, dan merupakan pelanggaran Hak Cipta dengan menggunakan hak eksklusif tanpa ijin.

2. Perlindungan hukum bagi pemegang lisensi dengan melakukan upaya hukum berupa gugatan ke Pengadilan Niaga pada Pengadilan Negeri Semarang, dengan dasar gugatan perbuatan melawan hukum dan meminta ganti rugi kepada Pihak PT. SSM.

\section{DAFTAR PUSTAKA}

As'Edi, Adi. (2012). Hukum Acara Perdata Dalam Perspektif Mediasi (ADR) di Indonesia. Yogyakarta: Graha Ilmu.

Anjelfa, Ria. (2015, September). Perlindungan Hukum Atas Karya Hasil Rekaman Suara Yang Dikonversi Dalam Bentuk Compact Disk. Jurnal Notarius, Edisi 08 No. 2

Damian, Eddy. (2004). Hukum Hak Cipta: UUHC No. 19 Tahun 2002. Bandung : Alumni.

Firmansyah, Hery. (2011). Perlindungan Hukum Terhadap Merek, Yogyakarta : Pustaka Yustisia, Cetakan 1.

Hidayati, Endar. (2014, Agustus 29). Komersialisasi Hak Kekayaan Intelektual (HKI) Melalui Lisensi”, Makalah, disampaikan pada Workshop Lisensi dan Komersialisasi HKI Bagi Dosen Universitas Negeri Yogyakarta.

Hidayah, Khoirul. (2007). Hukum Hak Kekayaan Intelektual. Malang: Setara Press.

Ismail \& Randi, Mohammad. (2018). Upaya 
Hukum Kasasi Terhadap Putusan Pengadilan Niaga Atas Gugatan Pelanggaran Hak Cipta Menurut UndangUndang Nomor 28 Tahun 2014 Tentang Hak Cipta.Jurnal Lex Privatum. Vol. 6 No. 3

Khairandy, Ridwan \& Malik, Camelia. (2007). Good Corporate Governance. Yogyakarta: Kreasi Total Media.

Khairandy, Ridwan. (2009). Perseroan Terbatas; Doktrin, Peraturan Perundangundangan, dan Yurisprudensi. Yogyakarta: Kreasi Total Media.

Maarif, As'ari. (2017). Perlindungan Hukum Terhadap Pemegang Hak Cipta Berdasarkan UU No. 28 Tahun 2014 Tentang Hak Cipta" (Studi Kasus Terhadap perkara No. 353/Pid.Sus/2015/PN.SMN). Jurnal Kajian Hasil Penelitian Hukum.(Vol 1 (2) p.128-155).

Nainggolan, Bernard. (2011). Pemberdayaan Hukum Hak Cipta dan Lembaga Manajemen Kolektif. Bandung : PT. Alumni Bandung.

Purwaningsih, Endang. (2005). Perkembagan Hukum Intellectual Property Rights. Bogor : Ghalia Indonesia.

Peraturan Pemerintah Nomor 45 Tahun 2014 Tentang Penerimaan Negara Bukan Pajak.

Putusan Nomor $\quad$ 01/PDT.SUS-
HKI/2015/PN.NIAGA.

Putusan Nomor 517 K/Pdt.Sus-HKI/2015

Peraturan Pemerintah Nomor 36 Tahun 2018 Tentang Pencatatan Perjanjian Lisensi Kekayaan Intelektual

Rahmi, Janed \& Nasution, Parinduri. 2013. Interface Hukum Kekayaan Intelektual dan
Hukum Persaingan. Jakarta: Raja Grafindo Persada.

Ridho, Ali. (1986). Badan Hukum dan Kedudukan Badan Hukum Perseroan, Perkumpulan, Koperasi, Yayasan, Wakaf. Bandung: Alumni.

Riswandi, Budi Agus. (2008). Mengenal Hak Kekayaan Intelektual, Modul Kuliah Hukum Kekayaan Intelektual, FH-UII, Yogyakarta.

Rumbekwan, Richard G.E. (2016). Penyelesaian Sengketa Akibat Terjadinya Pelanggaran Hak Cipta di pengadilan Niaga.Jurnal Lex Crimen Volume V/No. 3/Mar. 2016.

Ruslan, Saleh. (1991). Seluk Beluk Praktis Lisensi. Jakarta: Sinar Grafika.

Sudargo, Gautama \& Winata, Rizawanto. (1997). Konvensi-Konvensi Hak Milik Intelektual Baru Untuk Indonesia. Bandung : Citra Aditya.

Saidin. (1995). Aspek Hukum Hak Kekayaan Intelektual (Intellectual Property Rights). Jakarta: Rajawali Press.

Saidin, OK. (2006). Aspek Hukum Hak Kekayaan Intelektual. Jakarta: Raja Grafindo Persada.

Usman, Rachmadi. (2003). Hukum Hak atas Kekayaan Intelektual: Perlindungan dan Dimensi Hukum.

Undang-Undang Nomor 5 Tahun 1999 Tentang Larangan Praktik Monopoli dan Persaingan Usaha Tidak Sehat

Undang-Undang Nomor 19 Tahun 2002 Tentang Hak Cipta.

Undang-Undang Nomor 28 Tahun 2014 
Tentang Hak Cipta.

Widjaja, Gunawan. (2001). Lisensi. Jakarta:

Rajawali Pers. 